Received: June 30,2021

Accepted: September 27,2021

\title{
DEPENDENCE OF THE RESTORATIVE EFFECT OF MACROPOROUS POLY(N-[2-HYDROXYPROPYL]-METHACRYLAMIDE HYDROGEL ON THE SEVERITY OF EXPERIMENTAL LACERATIVE SPINAL CORD INJURY
}

\author{
Abdallah Ibrahim ${ }^{1}$, Medvediev Volodymyr ${ }^{2}$, Draguntsova Nataliya ${ }^{3}$, Voitenko Nana ${ }^{4}$, \\ Tsymbaliuk Vitaliy ${ }^{5}$ \\ ${ }^{1} \mathrm{PhD}$ student, Department of Neurosurgery, Bogomolets National Medical University, Ukraine \\ ${ }^{2}$ Doctor of Medical Sciences, Professor of the Department of Neurosurgery, Bogomolets National Medical \\ University, Ukraine \\ ${ }^{3}$ Researcher of the Laboratory of Experimental Neurosurgery, The State Institution "Romodanov Neurosurgery \\ Institute, National Academy of Medical Sciences of Ukraine", Ukraine \\ ${ }^{4}$ Doctor of Biological Sciences, Professor, Head of the Department of Sensory Signalling, Bogomoletz \\ Institute of Physiology of National Academy of Sciences of Ukraine, Ukraine \\ ${ }^{5}$ Doctor of Medical Sciences, Professor, Academician of the National Academy of Sciences and National \\ Academy of Medical Sciences of Ukraine, Head of the Department of Neurosurgery, Bogomolets National \\ Medical University, Ukraine
}

\begin{abstract}
The aim of the study was to detect the macroporous poly(N-[2-hydroxypropyl]-methacrylamide hydrogel (PHPMA-hydrogel, $H G$ ) restorative effect dependence on the severity of the laceration spinal cord injury in young organisms. The male rats sample ( 1-month-old, $\sim 50 \mathrm{~g}$, inbred Wistar line) was represented with 4 experimental groups: 1) spinal cord lateral hemisection at the level of $\sim T_{12}-T_{13}$ segments (Sect; $\left.\left.n=11\right) ; 2\right)$ spinal cord lateral hemiexcision $\sim 1 \mathrm{~mm}$ long at the similar level (Exc; $n=8) ; 3)$ spinal cord lateral hemisection at the similar level with immediate implantation of the hydrogel fragment into the trauma region (HGsect; $n=11)$; 4) spinal cord lateral hemiexcision at the similar level with immediate implantation of the hydrogel fragment into the affected region (HGexc; $n=6)$. The motor function and spasticity of the paretic hindlimb was estimated respectively by the technically modified Basso-Beattie-Bresnahan (BBB) and Ashworth, conditionally blinded to individual characteristics of all operated animals and previous study results. The observation lasted for $\sim 5$ months. The criteria of non-inclusion were as follows: the ipsilateral hindlimb function level in a week after the injury $>9$ points $B B B$, and the contralateral hindlimb function level during prolonged period $\leq 14$ points $B B B$. The results were interpreted and presented according to the standardized time scale with interpolatory representation of the motor function and spasticity individual level in certain cases. Asymptotic stage differences between the studied groups and subgroups were stated during the first three weeks as well as in 8 weeks and 3 months after the injury. We found out that in a week after injury the motor function level in group Exc made up $0.9 \pm 0.5$ points $B B B$, in group HGexc $-3.6 \pm 1.2$

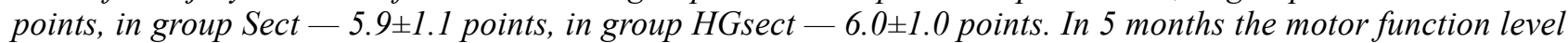
in group Sect made up $9.5 \pm 1.0$ points BBB, in group HGsect - 9.5 1.1 points, in group Exc - $0.8 \pm 0.3$ points,

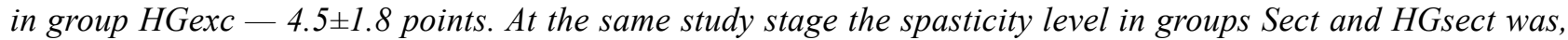
respectively, $0.8 \pm 0.2$ and $0.8 \pm 0.3$ points Ashworth, in group HGexc - $1.8 \pm 0.7$ points, in group Exc - 3.6 \pm 0.3 points. Throughout the study no significant differences in groups Sect and HGsect have been detected, and in groups Exc i HGexc such differences were detected only in 5 weeks after the injury. The considerable difference of spasticity in groups Sect and HGsect was noted in 1 week after the injury, in groups HGexc and Exc - during first 2 months of the experiment. In groups Sect and Exc reliable difference of both motor function and spasticity level was found at all study stages. In groups HGsect and HGexc considerable difference of the motor function level was characteristic at all stages, except for the end of the 1st and 7th weeks, whereas spasticity level differences
\end{abstract}


throughout the study remained insignificant. So, the tested hydrogel in young organisms shows positive effect only with severe trauma stages accompanied with extensive spinal cord defect.

Key words: $\underline{\text { spinal cord injuries, hindlimb, paresis, } \text { muscle spasticity, spinal cord regeneration, hydrogels. }}$

Introduction. Spinal cord injury (SCI) in most cases represents a complex nervous system injury, which significantly deteriorates life quality and decreases life span of the patients (DeVivo, 2012; Pretz, Kozlowski, Chen, Charlifue \& Heinemann, 2016). The estimated annual global SCI occurrence equals $\sim 1$ million people, with $\sim 27$ million people affected (GBD 2016 Traumatic Brain Injury and Spinal Cord Injury Collaborators, 2019), which more often relates to the middle-aged males (Singh, Tetreault, Kalsi-Ryan, Nouri \& Fehlings, 2014) and causes lifelong disability in half of all cases (DeVivo, 2012).

The gravest consequence of the SCI, not to mention its quite significant mortality (DeVivo, 2012), is manifested as the loss of motor and other spinal cord functions below the affected region, which is accompanied with the autonomic imbalance (Hou \& Rabchevsky, 2014; Hamid et al., 2018), spasticity syndrome (Nielsen, Crone \& Hultborn, 2007; Holtz, Lipson, Noonan, Kwon \& Mills, 2017), chronic pains (Finnerup et al., 2014), as well as affective (Lee, Nam, Kim \& Hwang, 2019; Wan, Chien, Chung, Yang \& Tzeng, 2020) and even cognitive disorders (Sachdeva, Gao, Chan \& Krassioukov, 2018). Regarding this, average cost of the spinal trauma treatment and care in countries with high income level is dramatically high (Krueger, Noonan, Trenaman, Joshi \& Rivers, 2013; Oliveri, Bello \& Biering-Sørensen, 2014).

The SCI functional impairment is associated with the neurons and nerve fibers traumatic death, and its clinical picture primarily reflects disruption of the efferent spinal neurons voluntary innervation due to breakdown of the descending spinal cord projections. So, the priority task of the biotic SCI restorative treatment is restoration of the motoneurons projection cortical innervation. The solution of the problem is related to the development of tissue neuroengineering transplantation mechanisms (Ahuja \& Fehlings, 2016; Ahuja et al., 2017; Liu, Schackel, Weidner \& Puttagunta, 2018; Wang, Tan \& Hui, 2018; Liu, Xie \& Wang, 2019; Zhang et al., 2019; Shah, Peterson, Yilmaz, Halalmeh \& Moisi, 2020), as well as the method of axon growth stimulation through the trauma region (Gao et al., 2016; Hanna et al., 2016) and smoothing effect of the factors which depress axonogenesis (Ahuja \& Fehlings, 2016; Paveliev et al., 2016). An alternative technology — bionic prosthetics used for the SCI, particularly, «powered exoskeletons» is now developing more effectively (Mekki, Delgado, Fry, Putrino \& Huang, 2018; Dijkers, Akers, Dieffenbach \& Galen, 2019; Shah et al., 2020). Though, it can be applied only with the minimum conscious paretic extremities motor activity as well as the coordinated function of the urinary system and absent spasticity syndrome, i.e. with certain amount of the preserved or restored long projection descending spinal cord fivers.

Modern transplantation methods applied for the SCI combine cells of various differentiation with polymer matrices (Liu et al., 2018; Wang et al., 2018). Macroporous poly(N-[2-hydroxypropyl]-methacrylamide) hydrogel (PHPMA-hydrogel), also known as NeuroGel ${ }^{\mathrm{TM}}$ (Woerly, Plant \& Harvey, 1996; Woerly et al., 1998; Woerly et al., 1999; Woerly, Doan, Evans-Martin, Paramore \& Peduzzi, 2001; Woerly, Doan, Sosa, de Vellis \& Espinosa, 2001; Woerly, Pinet, de Robertis, Van Diep, \& Bousmina, 2001; Woerly, Doan, Sosa, de Vellis \& Espinosa-Jeffrey, 2004; Woerly et al., 2005; Pertici et al., 2013), is a most prospective matrix. Previous studies showed have shown positive effect of the immediate PHMA-hydrogel implantation to the injury focus in the mature murine spinal cord complete section on the $T_{9}$ level, with excision of a 2-mm fragment (Woerly et al., 1998; Woerly et al., 1999), in the mature murine spinal cord complete section on the $T_{5}$ spinal cord level, with excision of a 3-mm fragment (Woerly et al., $2001 \mathrm{c}$ ), and in the mature feline spinal cord complete section on the $\mathrm{T}_{6}-\mathrm{T}_{7}$ level, with excision of a 3-mm fragment (Woerly et al., 2001 b; Woerly et al., 2004). Another study confirms positive effect of the delayed PHPMA-hydrogel implantation into the mature murine spinal compression injury on the $T_{8} / T_{0}$ level after excision of the scar tissue (Woerly et al., 2001 a). At last, positive effect of the immediate PHPMA-hydrogel implantation was detected in the spinal cord lateral hemisection of the neonate rat on the $\mathrm{T}_{10}$ level (Woerly et al., $2001 \mathrm{c}$ ), as well as in the 3 $\mathrm{mm}$ spinal cord hemiexcision on the $\mathrm{T}_{5}$ level in a mature rat (Pertici et al., 2013). Here, only two studies monitored the paretic extremities motion function using the Basso-Beattie-Bresnahan (BBB) (Woerly et al., $2001 \mathrm{a}$; Pertici et al., 2013).

It is noteworthy, that the spinal cord compression or contusion model, which is the closest to the clinical conditions (Alizadeh, Dyck \& Karimi-Abdolrezaee, 2019), due to evident reasons can be applied only for the liquid substance trials. The complete section model is quite easily reproduced (Alizadeh et al., 2019), characterized by uniformity of neurological deficiency and low autogenous restoration of the animals' posterior extremities motion function (Ung, Lapointe, Tremblay, Larouche \& Guertin, 2007), due to which it is the most convenient for the volume transplants restorative effect studies (Alizadeh et al., 2019). Though, its use is extremely dependent on high-quality veterinary care, accompanied with significant suffering of the study animals. In this sense the lateral hemisection model could be considered as the compromise one, but for the difficulty of the intra-operational 
section preciseness assessment and considerable autogenous restoration of the murine spinal cord after such injury (Mills, Hains, Johnson \& Hulsebosch, 2001; Webb \& Muir, 2002; Arvanian et al., 2009; Zhao et al., 2015).

All this considered, as well as the popular idea about dependence of the nervous system regeneration potential on body age (Schwab \& Bartholdi, 1996; Jaerve, Schiwy, Schmitz \& Mueller, 2011; Geoffroy, Hilton, Tetzlaff \& Zheng, 2016; Geoffroy, Meves \& Zheng, 2017; Sutherland \& Geoffroy, 2020), the authors studied the dependence of the immediate PHPMA-hydrogel injury focal implantation restorative effect on the severity of the lateral laceration spinal injury in young animals.

Methods. White outbred rats (inbred derivatives of Wistar rats), aged $\sim 1$ month, weighting $\sim 50 \mathrm{~g}$, obtained from the Animal Facility of Bogomoletz Institute of Physiology were used in the study. The rats were kept under the temperature ranging within $\sim 18-22^{\circ} \mathrm{C}$, natural circadian lighting, permanent room ventilation and balanced diet ad libitum. During the study the authors observed rules of bioethics and treatment of animals, according to the EU Council Directive 86/609/EEC «On the approximation of laws, regulations and administrative provisions of the Member States regarding the protection of animals used for experimental and other scientific purposes" (1986), the European Convention for the Protection of Vertebrate Animals Used for Experimental and other Scientific Purposes (1986) and the Law of Ukraine №3447-IV “On Animal Protection from Cruel Treatment" (2006).

The study was designed to include 4 experimental groups: 1) lateral hemisection of the spinal cord on the $\sim \mathrm{T}_{12}-\mathrm{T}_{13}($ Sect; $\left.\mathrm{n}=11) ; 2\right)$ lateral hemiexcision of the spinal cord, $\sim 1 \mathrm{~mm}$ in length, on the same level (Exc; $\mathrm{n}=8)$; 3) lateral hemisection of the spinal cord on the same level with immediate PHPMA-hydrogel implantation into the injured region (HGsec; $n=11$ ); 4) lateral hemiexcision of the spinal cord, $\sim 1 \mathrm{~mm}$ in length, on the same level, with immediate PHPMA-hydrogel implantation into the injured region (HGex; $n=6)$.

PHPMA-hydrogel is a polymer material, synthesized in the laboratory of Dr Eric Pinet (FISO Technologies Inc., Quebec, Canada) from N-(2-hydroxypropyl) metacrylamide under heterophase separation by radical polymerization in the pore-forming medium, with divynyl transverse bonding. After cleaning secondary compounds and high-temperature sterilization, the PHPMA-hydrogel macrofragments are transported in airproof containers filled with distilled water, and provided for this project by Dr Yuriy Yaminsky. The native PHPMA-hydrogel is characterized with complicated amorphous volume structure, containing numerous micro$(<2 \mathrm{~nm})$, meso- $(2-50 \mathrm{~nm})$ and macro-pores (50-300 nm) (Woerly et al., 1999; Woerly et al., 2001 b).

In group Sect left-side spinal cord hemisection in the lower thoracic region was performed $(f i g .1 \mathrm{a})$. Operative interventions were performed under general anesthesia by intra-peritoneal introduction of xylazine $(\sim 15 \mathrm{mg} /$ $\mathrm{kg}$, "Biowet", Poland) and ketamine ( 70 mg/kg, PJSC «Farmak», Ukraine) solutions, with aseptic regulations observed sparingly toward the animals, and, in most cases - on warmed operation table. In this one, as well as the previous studies (Kopach et al., 2017; and others) the injury modeling region was chosen by palpation of the deeply anesthetized animal thorax caudal margin in the locus of its attachment to the spinal cord. Regarding theoretically lower ossification in young animals and especial anatomy of the last rib pairs (costae fluctuantes; Özkan, 2007; Olude, Mustapha, Ogunbunmi \& Olopade, 2013), the surgeon should locate the intervention region, after detecting apex of the angle between the ribcage and vertebral column above the middle $\mathrm{T}_{13}$. This, altogether with absent surgical visualization of necks of the rib, their attachment to the vertebral column and roentgenological control, provides for localization of the laminectomy region approximately, most probably — on the level of $\mathrm{T}_{11}-\mathrm{T}_{12}$, i.e., considering approximate skeletopic data (Gilerovich et al., 2008; Moonen et al., 2016), corrected according to the animal's age (Gelderd \& Chopin, 1977; Curless, Nelson, Brimmer \& Tellez, 1977) — on the spinal cord segments $\sim \mathrm{T}_{12}-\mathrm{T}_{13}$. After linear section of the shaved and antiseptic-cured skin on the $\sim \mathrm{T}_{9}-\mathrm{L}_{2}$ level and the posterior vertebral column surface skeletization, the inter-arch space was perforated with a spear-like steel pin; laminectomy, limited on the right, was performed with the bended on the rib "mosquito" forceps. No detection of the dura mater condition within the bone window and separation of the spinal cord from adjacent nerve trunks was conducted before the SCI modeling. The surgeon, using the insulin needle, vertically thoroughly punctured spinal cord, as close as possible to the posterior (dorsal) median vein (Zhang et al., 2001; Cao et al., 2015; Li, Xu Cao \& Wu, 2020) and/or artery (Scremin, 2015; Mazensky, Flesarova \& Sulla, 2017) left margin, trying to preserve perpendicular position of the needle towards the spinal cord dorsal surface. One of the ophthalmological scissor jaws was introduced into the spinal cord injury, the second jaw was aimed at the left half of the spinal cord breadth with the nerve roots branches, to dissect it in a few stages. The joined jaws of the rib-curved ophthalmological scissors were introduced into the section region, and, bearing with the working tip against the anterior vertebral column canal surface, the surgeon proceeded by its internal surface, from the midline to the arch root break. Due to this, the probability of incomplete section of the spinal cord white matter was decreased, the anterior roots trunks were thus injured, which was often accompanied with synchronous motor responses. The PHPMA-hydrogel fragment was then implanted into the spinal cord injury region of the HGsect animals (fig. 1 b).

In group Exc the left-side hemiexcision in the inferior thoracic region was reproduced (fig. $1 \mathrm{c}$ ). As with the previous model, after laminectomy limited on 
the right, performed for deeply anesthetized animals, without assessment of the dura mater condition and separation of adjacent nerve trunks, the surgeon used insulin needle to puncture the spinal cord as close as possible to the left side of the posterior median vein and/or artery (see above). The same thorough punctures were performed $\sim 0.5 \mathrm{~mm}$ rostrally and caudally. In every two neighbor punctures a jaw of the expanded ophthalmological scissors was introduced, to make the longitudinal paramedian spinal cord section in several stages, with $\sim 1 \mathrm{~mm}$ interval. Sequentially, an ophthalmological scissors jaw was introduced into the rostral or caudal injury end, the second jaw aimed at the left half of the spinal cord breadth together with the nerve roots trunks, to intersect it in a few stages. The spinal cord matter within the fragment was removed using the curved and direct ophthalmological scissors, under

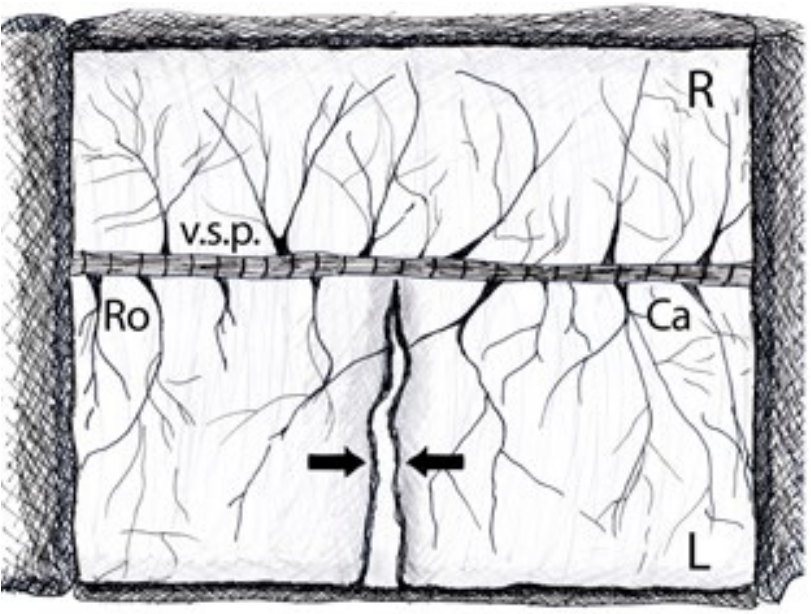

a

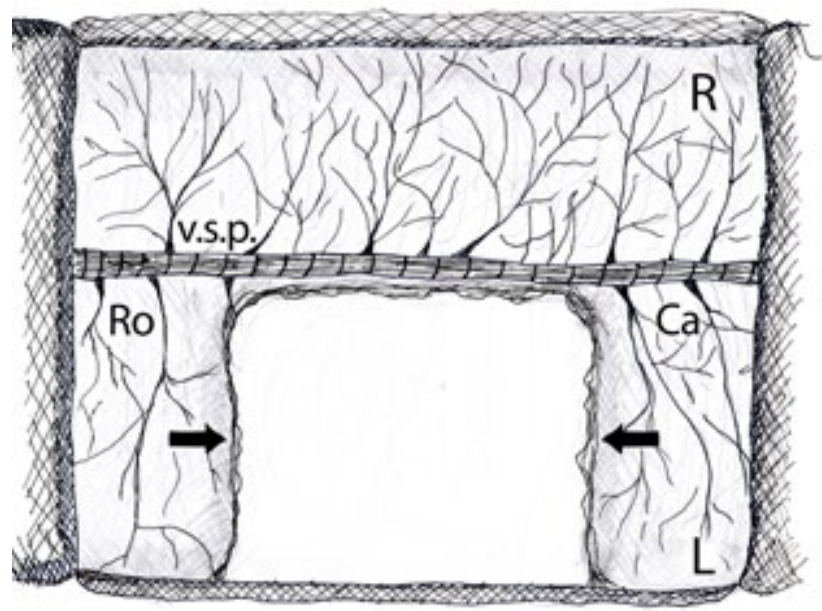

C operational microscope magnification during 20-30 min. In several cases visually non-vital fragments of the spinal cord matter were removed. In HGexc animals the PHPMA-hydrogel was implanted into the spinal cord injury focus $(f i g .1 d)$.

In both groups after spontaneous bleeding arrest and the spinal cord wound cleaning access hole into the spinal canal was covered with specially excised in the accessed area fragment of subcutaneous connective cellular tissue, soft tissues and skin stitched with two rows of interrupted stitches. The injury region was cured with povidone-iodine solution (EGIS, Hungary). In order to prevent infectious complications, bicillin-5 solution (PJSC «Kyivmedpreparat», Ukraine), dosed $\sim 0.5 \mathrm{mln} \mathrm{U} / 1 \mathrm{~kg}$ was introduced subcutaneously in the posterior cervical region. Anti-inflammatory and antioedemic therapy was represented with intra-peritoneal introduction of dexa-

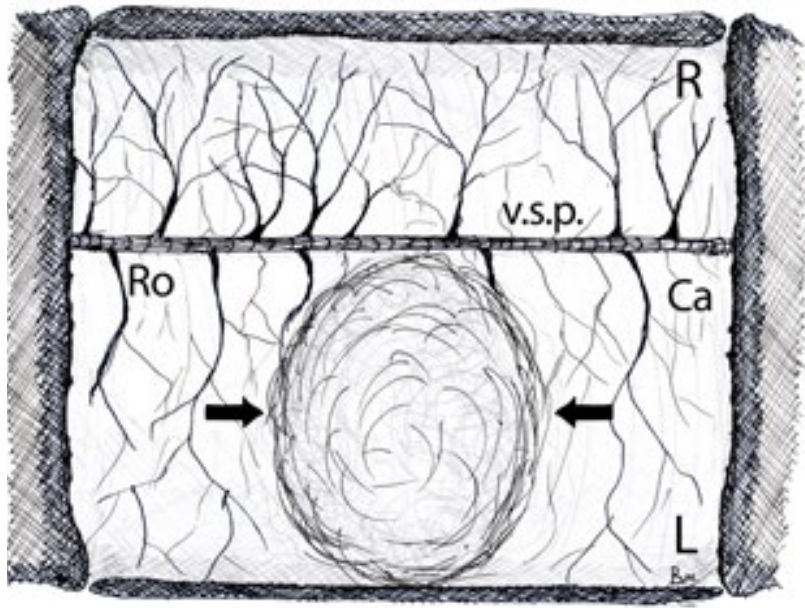

b

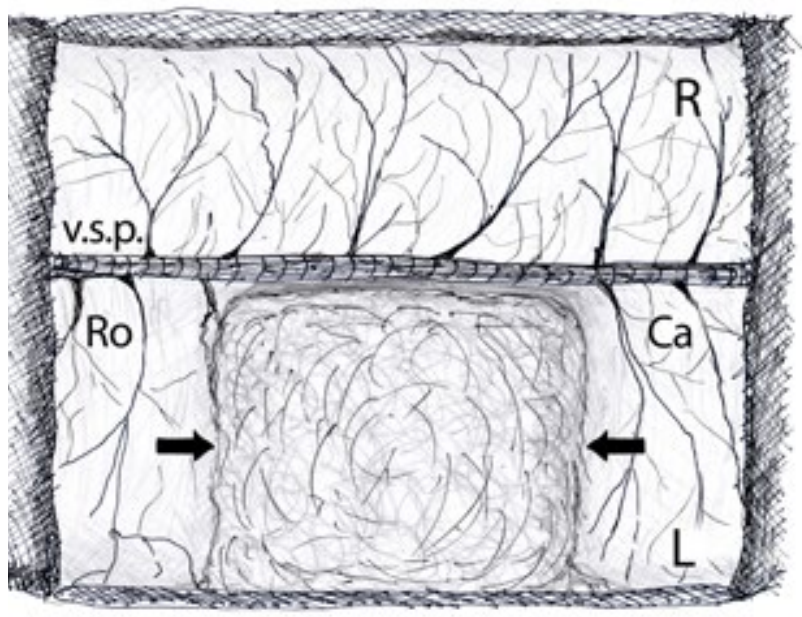

d

Fig. 1. General view of the surgical wound after lateral hemisection (a) or after lateral hemiexcision (c) of the young murine spinal cord in the inferior thoracic region and immediate PHPMA-hydrogel implantation into the injury focus (b, d). Scheme. Ro - rostral, $\mathrm{Ca}$ - caudal, $\mathrm{R}$ - right-side, L — left-side, v.s.p. — vena spinalis posterior (dorsalis). The injury focus and implantation region are outlined with arrows. The posterior spinal cord vessels (vena et arteria spinalis posterior) branching is shown nominally 
methasone solution (KRKA, Slovenia), $\sim 5 \mathrm{mg} / \mathrm{kg}$ of body weight. After operation and until their complete awakening the animals were kept under increased air temperature. In order to prevent ophthalmological complications, in most cases the exterior part of the eyeball after the operation was moistened with the saline in drips. Further, the animals were kept in special cages of larger (2-3 animals; subgroup of the Sect group, $n=6,2$ cages; group HGexc) or smaller (one animal; rest of the Sect group, animals of the HGsect $i$ Exc) size.

Function Index (FI) of the ipsilateral to the injury region hindlimb was evaluated according to the BBB scale (Basso, Beattie \& Bresnahan, 1995), used in the authors' own technical modification, during observation of the animals motor activity on horizontal open space of non-defined shape, area, size, smoothness and nature, without video-registration as well as registration of the time and duration of such observation. To define the FI levels between 16 and 17 points occasionally, a personal criterion was used: positioning the foot related to the rostral-caudal axis, with abrupt raising posterior part of the animal body by its tail and immediate recovery of its previous position, without getting the anterior extremities off the horizontal surface. Parallel positioning of the foot related to the axis during getting it off the ground and during its contact with surface was considered as 17 points, foot rotation during getting it off the surface -16 points. The distinction between these two meanings within the original protocol frames is, due to the authors, rather problematic (Basso et al., 1995), and some authors (Metz, Merkler, Dietz, Schwab \& Fouad, 2000) offer to evaluate the foot position and getting the thumb off the surface during the step motion as separate issues.

The spasticity index (SI) of the ipsilateral to the injury region hindlimb was evaluated using the adjusted to experimental conditions Ashworth scale (Dong, Wang, Zhang \& Han, 2005), in authors' technical modification, without acclimatization exercising and relaxation blinding of the animals, the animal in horizontal position held by its tail during various kinds of motor behavior. In order to verify slight spastic paresis ( 0.5 points $)$, the original criteria were used: better sensitivity in the paretic hindlimb than in conventionally intact one (contralateral), trembling during pulling the animal by its foot to the side and/or hypermetric extension of the paretic hindlimb during postural reaction to its abrupt traction by the tail along horizontal surface. The meaning of the FI equal to 0 and $\geq 1$ points was detected with passive motions in the ankle-joint, 0 point was registered with absent resistance, 1 point - with slight resistance, 2 points - with more significant resistance and preserved mobility under slight exertion, 3 points - with more or less passive mobility under quite strong but not algogenic exertion, 4 points - with limited passive mobility under such exertion.
The FI and SI data monitoring started after the $6^{\text {th }}$ day due to ethical considerations, by the same supervisor, conventionally blinded to the individual characteristics of all animals operated by him, as well as, to the previous FI and Si data. In case of doubt about precise integer value of the FI or SI, the half-value was registered.

The experimental groups non-eligibility criteria for animals were as follows: the FI level of the ipsilateral hindlimb in 1 week after the injury $>9$ points of BBB, the FI level of the contralateral hindlimb during prolonged observation period $\leq 14$ BBB points. Two animals were not considered eligible for the Sect group, three animals - for the Exc group, of which two with bilateral paresis; three animals were not eligible for the HGsect and HGexc groups, including one animal with bilateral paresis for the HGexc group.

The SI and FI monitoring results were depicted according to the standardized within the experiment time scale: during first two months - weekly (weeks 1-8), and in 3, 4 and 5 months after the injury, calculating last three terms by intervals between the same day data of two next months. In some cases, individual parameters of the FI an SI were reproduced interpolatively, as the average from two meanings obtained in two next time observation points. For all other cases with registered calendar data the asymptotic difference in real testing time between the groups and comparative analysis of pairs were detected during first three weeks of observation as well as in 8 weeks and 3 months after the injury ( $12-29 \%$ from the value of appropriate term of the result representation standardized time scale); as for the other terms, the differences didn't exceed $11 \%$.

The obtained SI and FI data received comparative statistical analysis with the STATISTICA 10.0 software, using the Mann-Whitney U-Test, Wilcoxon Matched Pairs Test and the Spearman Rank Order Correlations. The average values were represented as $\mathrm{M} \pm \mathrm{SE}$, where $\mathrm{M}($ mean ) - is an average of the value, SE (standard error) - standard error of the mean average. In all cases the hypothesis about statistical significance of the received results was supposed true if probability of the opposite statement truth was less than $0.05(p<0.05)$.

Results. The most characteristic trait of the restorative process changes in groups Sect and HGsect was their identity property (fig. 2). In one week after the injury (according to the standardized time scale) the FI in group Sect was 5.9 \pm 1.1 BBB points, in group HGsect $-6.0 \pm 1.0$ BBB points. The reliable increase of the FI in group Sect was limited to the first three observation weeks $(\mathrm{p}<0.05$ comparing different observation terms within the recalled time interval; Wilcoxon Matched Pairs Test). In group HGsect the significant increase of the FI was detected on the $2^{\text {nd }}, 4^{\text {th }}$ and $6^{\text {th }}$ observation weeks $(\mathrm{p}<0.05$ when comparing values in the recalled periods with values, respectively, on the $1^{\text {st }}, 2^{\text {nd }}$ and $5^{\text {th }}$ weeks; Wilcoxon Matched Pairs Test). The true 


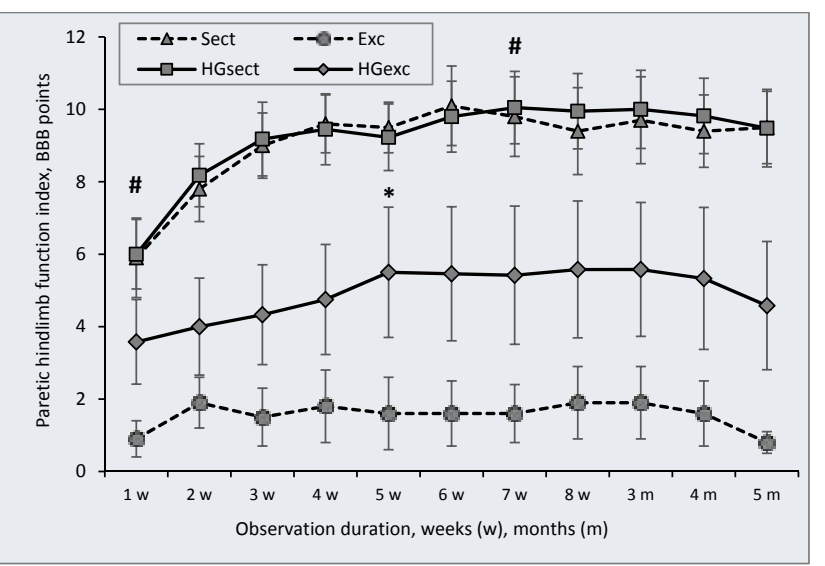

Fig. 2. Dynamic pattern of the FI (function index) of the paretic hindlimb in experimental groups during the defined observation period. No significant FI averages differences between groups Sect and HGsect were detected during the study ( $>0.05$; Mann-Whitney $U$ Test). For groups HGexc and Exc the differences were revealed only in 5 weeks after the injury $(\mathrm{p}<0.05$; Mann-Whitney U Test). When comparing each value in groups Sect and Exc, the significant difference was found at all study stages $(\mathrm{p}<0.05 ;$ Mann-Whitney $U$ Test). For pairs HGsect and HGexc the significant difference between the FI values was defined at all study stages, except for the end of the $1^{\text {st }}$ and $7^{\text {th }}$ weeks $(\mathrm{p}<0.05 ;$ Mann-Whitney U Test $)$.

Legend: * - significant difference between the FI value of group HGexc and FI value of group Exc was registered ( $p>0.05$; Mann-Whitney U Test); \#-no significant difference between the FI value of group HGsect and FI value of group HGexc ( $p<0.05$; Mann-Whitney U Test).

upper limit in group Sect $(10.1 \pm 1.1 \mathrm{BBB}$ points $)$ was noted in 6 weeks after the injury, in group HGsect in 7 weeks $(10.1 \pm 1.0$ BBB points; fig. 2). The final FI value in group Sect made up 9.5 \pm 1.0 BBB points, in group NGsect - 9.5 \pm 1.1 points. Group HGsect, unlike group Sect, was characterized by positive correlation of the average FI values and the observation duration value ( $r=0.77, p<0.05$; Spearman Rank Order Correlations). Throughout all the observation period the authors haven't identified significant difference between groups Sect and HGsect ( $\mathrm{p}<0.05$; Mann-Whitney U Test).

As with the FI, values and dynamic changes of the SI in groups Sect and HGsect turned to be substantially similar (fig. 3). The only observation term, during which significant FI difference in both groups was detected, was late first observation week (according to the standardized time scale; $\mathrm{p}=0.03$; Mann-Whitney U Test). At this time average SI values in groups Sect and HGsect made up, respectively, $0.3 \pm 0.1$ and $0.7 \pm 0.2$ Ashworth points. During the first month unreliable SI decrease till the lowest value was observed, $0.5 \pm 0.2$ Ashworth points, was registered in group HGsect. During the next two months' group HGsect showed gradual SI increase till its maximum value $(0.9 \pm 0.3$ Ashworth points $)$, which was registered in 3 and 4 months after the injury. During these two observation terms the authors registered reliable ( $\mathrm{p}<0.05$, Wilcoxon Matched Pairs Test) SI values difference in the group, compared to the values of the $4^{\text {th }}-6^{\text {th }}$ weeks (for the SI values in the end of the $3^{\text {rd }}$ month) and values of the $5^{\text {th }}-7^{\text {th }}$ weeks (for the SI values in the end of the $4^{\text {th }}$ month).

The SI changes in group Sect were characterized by two reliable extreme points (fig. 3 ): on the $2^{\text {nd }}-4^{\text {th }}$ weeks ( $0.6 \pm 0.1$ points of Ashworth; $p<0.05$ compared to the SI values in 1 week after the injury; Wilcoxon Matched Pairs Test) and on the $8^{\text {th }}$ week $(0.8 \pm 0.1$ Ashworth points; $p<0.05$ compared to the SI values in 1,4 and 5 weeks after the injury; Wilcoxon Matched Pairs Test). The final SI values in both groups were almost identical - 0.8 \pm 0.2 (group Sect) and 0.8 \pm 0.3 (group HGsect) Ashworth points, which was actual maximum for group Sect. Totally, group Sect had stronger significant positive correlation between the SI mean values and the

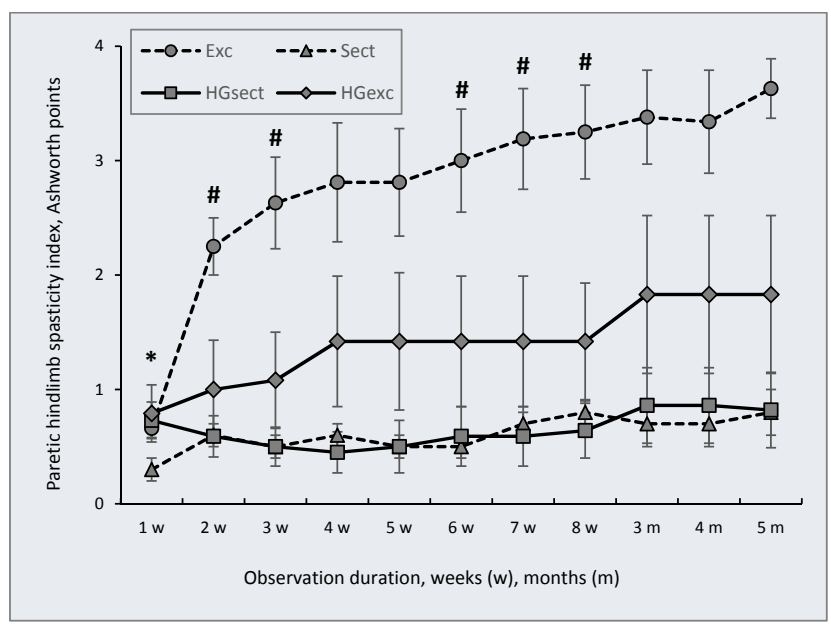

Fig. 3. Dynamic pattern of the spasticity index (SI) of the paretic hindlimb in experimental groups during the general observation period. For the SI averages the significant difference between groups Sect and HGsect was observed only in 1 week after the injury $(\mathrm{p}<0.05$;

Mann-Whitney U Test), and between groups HGexc and Exc - during the first two months ( $\mathrm{p}<0.05$; MannWhitney U Test). For SI values in groups Sect and Exc the significant difference was found at all study stages

( $<<0.05 ;$ Mann-Whitney U Test), for pairs HGsect

and HGexc, on the contrary, the SI values difference being insignificant across all the study ( $\mathrm{p}>0.05$; MannWhitney U Test).

Legend: * - significant difference between SI values in groups Sect and HGsect ( $p<0.05$; Mann-Whitney U Test); \#significant difference between SI values in groups HGexc and $\operatorname{Exc}(p<0.05 ;$ Mann-Whitney U Test). 
observation duration value $(r=0.83, p<0.05$; Spearman Rank Order Correlations); in group HGsect it was weak ( $r=0.6, p<0.05$; Spearman Rank Order Correlations).

The SI and FI changes in lateral hemiexcision turned out to be different. The mean FI value in group Exc in a week after the injury (according to the standardized time scale) made up $0.9 \pm 0.5 \mathrm{BBB}$ points (fig. 2), during the next weak it reached the actual, though, unreliable maximum value $(1.9 \pm 0.7 \mathrm{BBB}$ points; $p>0.05$ compared to the values in 1 and 3 weeks after the injury; Wilcoxon Matched Pairs Test). Further, the FI values made up 2 BBB points, and during the $4^{\text {th }}-5^{\text {th }}$ month they decreased to $0.8 \pm 0.3 \mathrm{BBB}$ points (fig. 2), which was significantly lower parameter than that in the end of the $2^{\text {nd }}$ observation week ( $\mathrm{p}=0.035$; Wilcoxon Matched Pairs Test). As in group Sect, during the experiment the FI average in group Exc didn't show significant correlation with the observation duration value $(r=0.02, p>0.05$; Spearman Rank Order Correlations).

The FI in group HGexc in 1 week after the injury (according to the standardized time scale) was 3.6 \pm 1.2 points of BBB, and it didn't change remarkably during the following observation ( $\mathrm{p}>0.05$; Wilcoxon Matched Pairs Test), reaching actual maximum (5.6 $\pm 1.9 \mathrm{BBB}$ points) during the $5^{\text {th }}-12^{\text {th }}$ weeks, making up $4.5 \pm 1.8$ BBB points at the final experiment stage.

Starting from the $6^{\text {th }}$ week, the FI changes in groups Exc and HGexc were parallel, with the only observation term where a significant difference between the FI value of group HGexc and FI value of group Exc was registered, being the end of the $5^{\text {th }}$ experiment week ( $p=0.038 ;$ Mann-Whitney U Test). As in groups Sect and Exc, during experiment the FI average value in group HGexc didn't show significant correlation with the observation duration ( $r=0.57, p>0.05$; Spearman Rank Order Correlations).

The SI changes after severe laceration were also characterized by several peculiarities (fig. 3). In 1 week after the injury (according to the standardized time scale), the SI meaning in group Exc made up $0.7 \pm 0.1$ points of Ashworth, during the next week a significant dramatic increase till $2.3 \pm 0.3$ points ( $\mathrm{p}=0.01$ compared to the first week values, Wilcoxon Matched Pairs Test) was observed. Further, the authors noted continued steady SI rise, which was substantial $(\mathrm{p}<0,05$; Wilcoxon Matched Pairs Test) on the $7^{\text {th }}$ week (compared to the values in 2 weeks after the injury), on the $3^{\text {rd }}$ month (compared to the values in 3 weeks after the injury), on the $4^{\text {th }}$ month (compared to the value in 5 weeks after the injury), and on the $5^{\text {th }}$ month (compared to the values in 5 and 6 months after the injury). The final SI value in group Exc reached $3.6 \pm 0.3$ points of Ashworth. The progredient increase of the paretic hindlimb spasticity level in group Exc during the experiment was also verified by the Spearman rank correlation between the SI averages and the observation duration $(r=0.99, p<0.05$; Spearman Rank Order Correlations).

In 1 week after reproducing the injury (according to the standardized time scale) the SI in group HGexc made up $0.8 \pm 0.3$ Ashworth points and during all study period it didn't show significant changes $(\mathrm{p}>0.05$; Wilcoxon Matched Pairs Test). The main segment of unreliable SI increase in the group was observed during the $2^{\text {nd }}$ and $4^{\text {th }}$ weeks (fig. 3); throughout all the $2^{\text {nd }}$ month it stayed without changes $(\sim 1.4$ Ashworth points $)$, and the latest nonsignificant SI increase was registered during the $3^{\text {rd }}-5^{\text {th }}$ months. The final SI value in the group was $1.8 \pm 0.7$ Ashworth points. Despite this, a significant correlation with the duration was found for the SI averages in group HGexc across the experiment ( $r=0.94$, $p<0.05$; Spearman Rank Order Correlations). The significant difference between groups HGexc and Exc was noted in 2, 3, 6, 7 and 8 weeks after the injury $(\mathrm{p}<0.05$; Mann-Whitney U Test).

Totally, the analysis of the FI and SI average pairs obtained during the general study period didn't show any correlations between the values $(p>0.05$; Spearman Rank Order Correlations). Instead, having analyzed the FI and SI individual values pairs during each term, a reliable ( $p<0.05$; Spearman Rank Order Correlations) negative correlation was observed in 1 and 4 weeks, 3 and 5 months after the injury (group Sect) and in 3, 5 and 6 weeks after the injury (group HGsect), in 5, 7, 8 weeks; in 3 and 4 months (group Exc), as well as at all study terms, except for the $1^{\text {st }}$ and $5^{\text {th }}$ weeks (group HGexc).

No significant FI averages differences between groups Sect and HGsect were detected during the study ( $\mathrm{p}>0.05$; Mann-Whitney U Test), and for groups HGexc and Exc - the differences were revealed only in 5 weeks after the injury $(\mathrm{p}<0.05 ;$ Mann-Whitney $U$ Test). As for the SI averages, the significant difference between groups Sect and HGsect was observed only in 1 week after the injury $(\mathrm{p}<0.05$; Mann-Whitney U Test $)$, and between groups HGexc and Exc - during the first two months $(\mathrm{p}<0.05 ;$ Mann-Whitney U Test $)$.

The degree of the spinal cord laceration spatial defect significantly affects the regeneration success - when comparing both FI and SI values in groups Sect and Exc, the significant difference was found at all study stages $(\mathrm{p}<0.05$; Mann-Whitney U Test). The PHPMA-hydrogel implantation into the injury focus, most probably, intensifies this effect: for pairs HGsect and HGexc the significant difference between the FI values was defined at all study stages, except for the end of the $1^{\text {st }}$ and $7^{\text {th }}$ weeks $(\mathrm{p}<0.05 ;$ Mann-Whitney U Test), with the SI values difference being insignificant across all the study $(\mathrm{p}>0.05$; Mann-Whitney U Test).

Discussion. Despite its low incidence, the SCI is a cumulative pathology which is widely spread, leading to significant deterioration of the victims' life quality, 
stipulating for considerable economic losses (DeVivo, 2012; Krueger et al., 2013; Oliveri et al., 2014; Pretz et al., 2016; GBD 2016 Traumatic Brain Injury and Spinal Cord Injury Collaborators, 2019). The most important pathophysiological components of the SCI early period are primary breakdown of the cerebral nerve fibers, cells and vessels in the injury focus; and the secondary injury of the perifocal region neurons and nerve fibers due to inflammatory process (Tran, Warren \& Silver, 2018; Alizadeh et al., 2019). The most clinically essential consequence of these processes is disruption of descending innervation of the spinal cord efferent neurons below the injury point. The causes of post-SCI limited descending pathways regeneration are: post-axonotomic apoptosis (Siebert, Middleton \& Stelzner, 2010; Conta Steencken, Smirnov \& Stelzner, 2011; Swieck et al., 2019), depressed oligodendria evolvement in the spinal cord tissues (Rao \& Pearse, 2016), as well as numerous axonal growth cones repellents expression in the scar region (Tran et al., 2018). Though, limited autogenous functional spinal cord regeneration is a well-known clinical issue (Steeves, 2015; Khorasanizadeh et al., 2019), which is most probably provided by restructuring of the motor system neuronal networks on supraspinal and spinal levels (Blesch \& Tuszynski, 2009; Ghosh et al., 2010; Nishimura \& Isa, 2012; Manohar, Foffani, Ganzer, Bethea \& Moxon, 2017; Brown \& Martinez, 2019; Zavvarian, Hong, \& Fehlings, 2020). In this sense, developing methods of stimulation and/or improvement of the neuronal networks plasticity is well-substantiated (Ahuja et al., 2017; Liu et al., 2018; Wang et al., 2018; Liu et al., 2019; Zhang et al., 2019).

Among the studies, dedicated to the effectiveness of the PHPMA-hydrogel implantation into the injury focus (Woerly et al., 1996; Woerly et al., 1998; Woerly et al., 1999; Woerly et al., 2001 a; Woerly et al., 2001 b; Woerly et al., 2001 c; Woerly et al., 2004; Woerly et al., 2005; Pertici et al., 2013), only two of them used lateral spinal cord hemisection performed to the mature rat on the thoracic level to reproduce the SCI (Woerly et al., 2005; Pertici et al. 2013), and only in one of them (Pertici et al. 2013) the authors used the paretic hindlimb motor function assessment by BBB scale for the restorative process analysis. The authors of the study implanted the PHPMA-hydrogel fragment into the unilateral 1-mm excision of the mature rat spinal cord (line Sprague-Dawley, males, 8 months, $300 \mathrm{~g}, n=15$ ) on the $\mathrm{T}_{10}$ level. According to the authors, in 14 weeks the FI value of the paretic hindlimb in main group reached $14.29 \pm 1.77$ BBB points, and in the experimental group (reproducing the same SCI without hydrogel implantation) $-8.66 \pm 1.25$ points. Opposite to this, according to our data, the FI values of the paretic hindlimb motor function recovery after similar injury on the $\sim \mathrm{T}_{11}-\mathrm{T}_{12 \text { level }}$ and subsequent PHPMA-hydrogel implantation, even obtained from the young animals, turned out to be much lower- $4.5 \pm 1.8$ (group HGexc) and $0.8 \pm 0.3$ BBB points (group Exc). We intentionally excluded animals with significant contralateral motor limitations from the calculation groups.

One of the possible causes of such result discordance may be the eligibility criteria (see above), according to which one animal wasn't included in group Exc, and two animals in group HGexc, with the FI values in a week after the injury over 9 BBB points. The FI values of these animals were, respectively, 14, 11.5 and 13 BBB points. Such approach was chosen in order to obtain the animal groups with the severest ipsilateral motor limitations against the significant autogenous regeneration potential, with its peculiar age characteristics (Schwab \& Bartholdi, 1996; Jaerve et al., 2011; Geoffroy et al., 2016; Geoffroy et al., 2017; Sutherland \& Geoffroy, 2020). The motives of such study design are evident: the effectiveness of any restorative intervention with the SCI should be verified with the severest traumas, minimizing suffering of the study animals.

The other differences in the study design, which could be theoretically applied to the detected difference between our results and the other authors (Pertici et al., 2013), are: differences of anesthesia protocol, application of cold spinal cord vasoconstriction before reproducing the SCI, precision section of the dura mater before reproducing the SCI, use of a different material for the implantation region segregation from the muscles, differences in postoperative care and animal housing, and, finally, differences between the animals lines and injury level. Besides, the authors don't describe intra-operational verification of the transverse spinal cord excision completeness, they only state about injury debridement from the non-vital tissues, mentioning only visual control of the spinal cord margins, which should not contain coverings and blood clots.

According to the obtained data, the PHPMA-hydrogel improves restoration of the motor function after the spinal cord hemiexcision (reliably - only in 5 weeks after the injury) and decreases spasticity in the paretic hindlimb (reliably - during 2 months after the injury). As figure 2 shows, considerable portion of the PHPMA-hydrogel positive functional effect is accumulated during the first week after the injury- during the strongest focal inflammatory process, which stipulated for the secondary spinal cord lesion (Alizadeh et al., 2019). One of such response triggers is, doubtlessly, destruction of numerous small vessels within the injury focus, and related to this local hemorrhage. As we have observed, the PHPMA-hydrogel just after its implantation significantly decreases bleeding in the injured spinal cord region. We suppose that this decreases imbibition of the adjacent spinal matter with blood, limits direct contact of the cerebral matter with liquor and, thus, eliminates an immune response enhancement way. If this turns out 
to be true, the early positive PHPMA-hydrogel effect will receive pathophysiological justification: its immediate after the injury implantation decreases secondary inflammatory lesion of the spinal cord. Doubtless is that the PHPMA-hydrogel applied to the spinal cord traumatic lesion creates axon regeneration growth environment (Woerly et al., 2001 b; Pertici et al., 2013). In particular, strong arguments in favor of the thorough invasion of axons through the PHPMA-hydrogel implantation region have been obtained using special nerve fibers tracing methods (Woerly et al., 2001 a; Woerly et al., 2001 b; Woerly et al., 2001 c).

The PHPMA-hydrogel implantation significantly decreases differences of the FI and SI values between two spinal cord laceration types, and, most probably, due to its early effect: the difference is absolute comparing the FI and SI values in groups Sect and Exc, it is incomplete comparing the FI values, and absent - comparing the SI values in groups HGsect and HGexc. Regarding considerable proximity of the FI and SI values in groups Sect and HGsect, this indirectly evidences about significant positive hydrogel effect against the injury with huge spinal cord lesion.

The absence of any considerable PHPMA-hydrogel implantation effect under the high autoregeneration potential and milder spinal cord injury (groups Sect and HGsect) shows that the effective spontaneous spinal cord restoration may successfully compensate for the injury consequences and in this way deprive the PHPMA-hydrogel, the restoration intensifier, from its uniqueness.

Technical warnings. One of the technical problems of our study and similar studies is impossibility of precise SCI level skeletotopic detection (see above). Another difficulty is doubtful relevance of the BBB scale for the spinal cord lateral hemisection cases. The relatively intact hindlimb, contralateral to the injury, is used by the animal for compensation of the present motor limitation, so, according to our observations, numerous difficulties are met differentiating between 8 and 9 scale points, using such criteria as keeping the body weight with the paretic hindlimb, anterior-posterior coordination of the four extremities locomotor motions, as well as the paretic foot positioning in various parts of the step cycle static stage. The negative consequences of this could be partially compensated observing similar methodological conditions of the FI assessment in all study groups. This is why the scale is quite often used for the assessment of the paretic hindlimb motor function after the rat spinal cord unilateral laceration trauma (Mills et al., 2001; Webb \& Muir, 2002; Arvanian et al., 2009; Hsieh et al., 2010; Pertici et al., 2013; Zhao et al., 2015; Zhang et al., 2016; Li et al.,
2017), but, also as with our study, usually not in order to study the relatively intact, contralateral hindlimb.

The main difficulties of the Ashworth scale are differentiation between the SI levels within 1 to 3 points, impossibility of eliminating the voluntary muscle tone in incomplete paresis and difficulty of the key spasticity characteristics - «catch»-phenomenon, or significant increase of the muscle resistance with accelerated stretching (Nielsen et al., 2007) - due to small size of the animal hindlimb. In spite of this, the Ashworth scale was chosen for the spasticity verification due to restricted informalve value of technically much more complicated alternative instrument - electroneuromyography, which is characterized by significant diversity of the individual results measurement (Cliffer et al., 1998), probably, due to impossibility of detecting the paretic muscle motor point.

Conclusions. Our authors' lower thoracic spinal cord lateral hemiexcision model reproduces quite similar deep unilateral motor limitations with considerable spinal cord function preservation. In young body, along with the considerable auto-regeneration potential, immediate PHPMA-hydrogel implantation into the laceration injury focus shows substantial positive effect only with huge spatial spinal cord lesion. Possible mechanisms of the restorative PHPMA-hydrogel implantation are represented with its immediate antihaemorrhagic effect, limited secondary alteration responses in the spinal matter and preconditions for axons regeneration in the trauma focus. Further studies are needed to verify these hypotheses probability.

Conflict of interests. The authors declare no potential conflict of interest, in any form; the paper was not and it will not be the subject of commercial interest or reward.

Financing. The study was not financed from any external sources.

Contribution of the authors (name and surname of the authors). Project concept - V.Ts., V.M..; research interventions - V.M., I.M.; behavioral analysis and neurological study - V.M., I.M.; statistical data analysisN.D.; manuscript and figures- V.M.; review and editing - N.V.; project administration- V.Ts., N.V.

Consent to publication. All authors have read and approved the final version of the manuscript. All authors have agreed to publish this manuscript.

Acknowledgments. We thank Dr Eric Pinet (FISO Technologies Inc., Quebec, Canada) for providing the PHPMA-hydrogel, and Dr Yuriy Yaminsky for providing hydrogel for our work. 


\section{LITERATURE}

Ahuja, C. S., \& Fehlings, M. (2016). Concise Review: Bridging the Gap: Novel Neuroregenerative and Neuroprotective Strategies in Spinal Cord Injury. Stem cells translational medicine, 5(7), 914-924.

Ahuja, C. S., Nori, S., Tetreault, L., Wilson, J., Kwon, B., Harrop, J., et al. (2017). Traumatic Spinal Cord Injury-Repair and Regeneration. Neurosurgery, 80(3S), S9-S22.

Alizadeh, A., Dyck, S. M., \& Karimi-Abdolrezaee, S. (2019). Traumatic Spinal Cord Injury: An Overview of Pathophysiology, Models and Acute Injury Mechanisms. Frontiers in neurology, 10, 282.

Arvanian, V. L., Schnell, L., Lou, L., Golshani, R., Hunanyan, A., Ghosh, A., et al. (2009). Chronic spinal hemisection in rats induces a progressive decline in transmission in uninjured fibers to motoneurons. Experimental neurology, 216(2), 471-480.

Basso, D. M., Beattie, M. S., \& Bresnahan, J. C. (1995). A sensitive and reliable locomotor rating scale for open field testing in rats. Journal of neurotrauma, 12(1), 1-21.

Blesch, A., \& Tuszynski, M. H. (2009). Spinal cord injury: plasticity, regeneration and the challenge of translational drug development. Trends in neurosciences, 32(1), 41-47.

Brown, A. R., \& Martinez, M. (2019). From cortex to cord: motor circuit plasticity after spinal cord injury. Neural regeneration research, 14(12), 2054-2062.

Cao, Y., Wu, T., Yuan, Z., Li, D., Ni, S., Hu, J., et al. (2015). Three-dimensional imaging of microvasculature in the rat spinal cord following injury. Scientific reports, $5,12643$.

Cliffer, K. D., Tonra, J. R., Carson, S. R., Radley, H. E., Cavnor, C., Lindsay, R. M., et al. (1998). Consistent repeated M- and H-Wave recording in the hind limb of rats. Muscle \& nerve, 21(11), 1405-1413.

Conta Steencken, A. C., Smirnov, I., \& Stelzner, D. J. (2011). Cell survival or cell death: differential vulnerability of long descending and thoracic propriospinal neurons to low thoracic axotomy in the adult rat. Neuroscience, 194, 359-371.

Curless, R. G., Nelson, M. B., Brimmer, F., \& Tellez, C. (1977). Brain and spinal cord lesions in the newborn rat. Laboratory animals, 11(4), 251-255.

DeVivo M. J. (2012). Epidemiology of traumatic spinal cord injury: trends and future implications. Spinal cord, 50(5), 365-372.

Dijkers, M. P., Akers, K. G., Dieffenbach, S., \& Galen, S. S. (2021). Systematic Reviews of Clinical Benefits of Exoskeleton Use for Gait and Mobility in Neurologic Disorders: A Tertiary Study. Archives of physical medicine and rehabilitation, 102(2), $300-313$.

Dong, H. W., Wang, L. H., Zhang, M., \& Han, J. S. (2005). Decreased dynorphin A (1-17) in the spinal cord of spastic rats after the compressive injury. Brain research bulletin, 67(3), 189-195.

Finnerup, N. B., Norrbrink, C., Trok, K., Piehl, F., Johannesen, I. L., Sørensen, J. C., et al. (2014). Phenotypes and predictors of pain following traumatic spinal cord injury: a prospective study. The journal of pain, 15(1), 40-48.

Gao, R., Li, X., Xi, S., Wang, H., Zhang, H., Zhu, J., et al. (2016). Exogenous Neuritin Promotes Nerve Regeneration After Acute Spinal Cord Injury in Rats. Human gene therapy, 27(7), 544-554.

GBD 2016 Traumatic Brain Injury and Spinal Cord Injury Collaborators (2019). Global, regional, and national burden of traumatic brain injury and spinal cord injury, 1990-2016: a systematic analysis for the Global Burden of Disease Study 2016. The Lancet. Neurology, 18(1), 56-87.

Gelderd, J. B., \& Chopin, S. F. (1977). The vertebral level of origin of spinal nerves in the rat. The Anatomical record, 188(1), 45-47.

Geoffroy, C. G., Hilton, B. J., Tetzlaff, W., \& Zheng, B. (2016). Evidence for an Age-Dependent Decline in Axon Regeneration in the Adult Mammalian Central Nervous System. Cell reports, 15(2), 238-246.

Geoffroy, C. G., Meves, J. M., \& Zheng, B. (2017). The age factor in axonal repair after spinal cord injury: A focus on neuron-intrinsic mechanisms. Neuroscience letters, 652, 41-49.

Ghosh, A., Haiss, F., Sydekum, E., Schneider, R., Gullo, M., Wyss, M. T., et al. (2010). Rewiring of hindlimb corticospinal neurons after spinal cord injury. Nature neuroscience, 13(1), 97-104.

Gilerovich, E. G., Moshonkina, T. R., Fedorova, E. A., Shishko, T. T., Pavlova, N. V., Gerasimenko, Y. P., et al. (2008). Morphofunctional characteristics of the lumbar enlargement of the spinal cord in rats. Neuroscience and behavioral physiology, 38(8), 855-860.

Hamid, R., Averbeck, M. A., Chiang, H., Garcia, A., Al Mousa, R. T., Oh S. J., et al. (2018). Epidemiology and pathophysiology of neurogenic bladder after spinal cord injury. World journal of urology, 36(10), 1517-1527.

Hanna, A., Thompson, D. L., Hellenbrand, D. J., Lee, J. S., Madura, C. J., Wesley, M. G., et al. (2016). Sustained release of neurotrophin-3 via calcium phosphate-coated sutures promotes axonal regeneration after spinal cord injury. Journal of neuroscience research, 94(7), 645-652.

Holtz, K. A., Lipson, R., Noonan, V. K., Kwon, B. K., \& Mills, P. B. (2017). Prevalence and Effect of Problematic Spasticity After Traumatic Spinal Cord Injury. Archives of physical medicine and rehabilitation, 98(6), 1132-1138.

Hou, S., \& Rabchevsky, A. G. (2014). Autonomic consequences of spinal cord injury. Comprehensive Physiology, 4(4), $1419-1453$.

Hsieh, T. H., Tsai, J. Y., Wu, Y. N., Hwang, I. S., Chen, T. I., \& Chen, J. J. (2010). Time course quantification of spastic hypertonia following spinal hemisection in rats. Neuroscience, 167(1), 185-198. 
Jaerve, A., Schiwy, N., Schmitz, C., \& Mueller, H. W. (2011). Differential effect of aging on axon sprouting and regenerative growth in spinal cord injury. Experimental neurology, 231(2), 284-294.

Khorasanizadeh, M., Yousefifard, M., Eskian, M., Lu, Y., Chalangari, M., Harrop, J. S., et al. (2019). Neurological recovery following traumatic spinal cord injury: a systematic review and meta-analysis. Journal of neurosurgery. Spine, 1-17. Advance online publication.

Kopach, O., Medvediev, V., Krotov, V., Borisyuk, A., Tsymbaliuk, V., \& Voitenko, N. (2017). Opposite, bidirectional shifts in excitation and inhibition in specific types of dorsal horn interneurons are associated with spasticity and pain post-SCI. Scientific reports, 7(1), 5884 .

Krueger, H., Noonan, V. K., Trenaman, L. M., Joshi, P., \& Rivers, C. S. (2013). The economic burden of traumatic spinal cord injury in Canada. Chronic diseases and injuries in Canada, 33(3), 113-122.

Lee, S. J., Nam, T. W., Kim, C. H., \& Hwang, J. M. (2019). Knowledge and attitude of nonpsychiatric physicians regarding suicide in spinal cord injury patients and need for structured psychiatric education for suicide prevention: A prospective survey pilot study. Medicine, 98(11), e14901.

Li, L. S., Yu, H., Raynald, R., Wang, X. D., Dai, G. H., Cheng, H. B., et al. (2017). Anatomical mechanism of spontaneous recovery in regions caudal to thoracic spinal cord injury lesions in rats. PeerJ, 5, e2865.

Li, P., Xu, Y., Cao, Y., \& Wu, T. (2020). 3D Digital Anatomic Angioarchitecture of the Rat Spinal Cord: A Synchrotron Radiation Micro-CT Study. Frontiers in neuroanatomy, 14, 41.

Liu, S., Schackel, T., Weidner, N., \& Puttagunta, R. (2018). Biomaterial-Supported Cell Transplantation Treatments for Spinal Cord Injury: Challenges and Perspectives. Frontiers in cellular neuroscience, 11, 430.

Liu, S., Xie, Y. Y., \& Wang, B. (2019). Role and prospects of regenerative biomaterials in the repair of spinal cord injury. Neural regeneration research, 14(8), 1352-1363.

Manohar, A., Foffani, G., Ganzer, P. D., Bethea, J. R., \& Moxon, K. A. (2017). Cortex-dependent recovery of unassisted hindlimb locomotion after complete spinal cord injury in adult rats. eLife, 6, e23532.

Mazensky, D., Flesarova, S., \& Sulla, I. (2017). Arterial Blood Supply to the Spinal Cord in Animal Models of Spinal Cord Injury. A Review. Anatomical record (Hoboken, N.J. : 2007), 300(12), 2091-2106.

Mekki, M., Delgado, A. D., Fry, A., Putrino, D., \& Huang, V. (2018). Robotic Rehabilitation and Spinal Cord Injury: a Narrative Review. Neurotherapeutics : the journal of the American Society for Experimental NeuroTherapeutics, 15(3), 604-617.

Metz, G. A., Merkler, D., Dietz, V., Schwab, M. E., \& Fouad, K. (2000). Efficient testing of motor function in spinal cord injured rats. Brain research, $883(2), 165-177$.

Mills, C. D., Hains, B. C., Johnson, K. M., \& Hulsebosch, C. E. (2001). Strain and model differences in behavioral outcomes after spinal cord injury in rat. Journal of neurotrauma, 18(8), 743-756.

Moonen, G., Satkunendrarajah, K., Wilcox, J. T., Badner, A., Mothe, A., Foltz, W., et al. (2016). A New Acute Impact-Compression Lumbar Spinal Cord Injury Model in the Rodent. Journal of neurotrauma, 33(3), 278-289.

Nielsen, J. B., Crone, C., \& Hultborn, H. (2007). The spinal pathophysiology of spasticity--from a basic science point of view. Acta physiologica (Oxford, England), 189(2), 171-180.

Nishimura, Y., \& Isa, T. (2012). Cortical and subcortical compensatory mechanisms after spinal cord injury in monkeys. Experimental neurology, 235(1), 152-161.

Oliveri, R. S., Bello, S., \& Biering-Sørensen, F. (2014). Mesenchymal stem cells improve locomotor recovery in traumatic spinal cord injury: systematic review with meta-analyses of rat models. Neurobiology of disease, 62, 338-353.

Olude, M. A., Mustapha, O. A., Ogunbunmi, T. K., \& Olopade, J. O. (2013). The vertebral column, ribs, and sternum of the African giant rat (Cricetomys gambianus waterhouse). TheScientific WorldJournal, 2013, 973537.

Özkan, Z.E. (2007). Macro-anatomical investigations on the skeletons of mole-rat (Spalax leucodon Nordmann) III. Skeleton axiale. Veterinarski arhiv, 77 (3), 281-289.

Paveliev, M., Fenrich, K. K., Kislin, M., Kuja-Panula, J., Kulesskiy, E., Varjosalo, M., et al. (2016). HB-GAM (pleiotrophin) reverses inhibition of neural regeneration by the CNS extracellular matrix. Scientific reports, 6, 33916.

Pertici, V., Amendola, J., Laurin, J., Gigmes, D., Madaschi, L., Carelli, S., et al. (2013). The use of poly(N-[2-hydroxypropyl]-methacrylamide) hydrogel to repair a T10 spinal cord hemisection in rat: a behavioural, electrophysiological and anatomical examination. ASN neuro, 5(2), 149-166.

Pretz, C. R., Kozlowski, A. J., Chen, Y., Charlifue, S., \& Heinemann, A. W. (2016). Trajectories of Life Satisfaction After Spinal Cord Injury. Archives of physical medicine and rehabilitation, 97(10), 1706-1713.e1.

$\underline{\text { Rao, S. N., \& Pearse, D. D. (2016). Regulating Axonal Responses to Injury: The Intersection between Signaling Pathways Involved }}$ in Axon Myelination and The Inhibition of Axon Regeneration. Frontiers in molecular neuroscience, 9, 33.

Sachdeva, R., Gao, F., Chan, C., \& Krassioukov, A. V. (2018). Cognitive function after spinal cord injury: A systematic review. Neurology, 91(13), 611-621. 


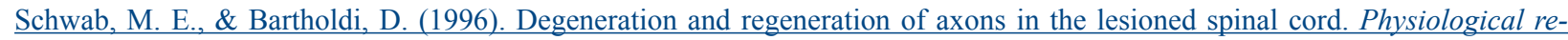
views, 76(2), 319-370.

Scremin, O. U. (2015). Cerebral vascular system. In G. Paxinos (Ed.), The rat nervous system (4th ed., pp. 985-1011). Elsevier.

Shah, M., Peterson, C., Yilmaz, E., Halalmeh, D. R., \& Moisi, M. (2020). Current advancements in the management of spinal cord injury: A comprehensive review of literature. Surgical neurology international, 11, 2.

Siebert, J. R., Middleton, F. A., \& Stelzner, D. J. (2010). Long descending cervical propriospinal neurons differ from thoracic propriospinal neurons in response to low thoracic spinal injury. BMC neuroscience, $11,148$.

Singh, A., Tetreault, L., Kalsi-Ryan, S., Nouri, A., \& Fehlings, M. G. (2014). Global prevalence and incidence of traumatic spinal cord injury. Clinical epidemiology, 6, 309-331.

Steeves J. D. (2015). Bench to bedside: challenges of clinical translation. Progress in brain research, 218, 227-239.

Sutherland, T. C., \& Geoffroy, C. G. (2020). The Influence of Neuron-Extrinsic Factors and Aging on Injury Progression and Axonal Repair in the Central Nervous System. Frontiers in cell and developmental biology, 8, 190.

Swieck, K., Conta-Steencken, A., Middleton, F. A., Siebert, J. R., Osterhout, D. J., \& Stelzner, D. J. (2019). Effect of lesion proximity on the regenerative response of long descending propriospinal neurons after spinal transection injury. BMC neuroscience, $20(1), 10$.

Tran, A. P., Warren, P. M., \& Silver, J. (2018). The Biology of Regeneration Failure and Success After Spinal Cord Injury. Physiological reviews, 98(2), 881-917.

Ung, R. V., Lapointe, N. P., Tremblay, C., Larouche, A., \& Guertin, P. A. (2007). Spontaneous recovery of hindlimb movement in completely spinal cord transected mice: a comparison of assessment methods and conditions. Spinal cord, 45(5), 367-379.

Wan, F. J., Chien, W. C., Chung, C. H., Yang, Y. J., \& Tzeng, N. S. (2020). Association between traumatic spinal cord injury and affective and other psychiatric disorders-A nationwide cohort study and effects of rehabilitation therapies. Journal of affective disorders, 265, 381-388.

Wang, Y., Tan, H., \& Hui, X. (2018). Biomaterial Scaffolds in Regenerative Therapy of the Central Nervous System. BioMed research international, 2018, 7848901.

Webb, A. A., \& Muir, G. D. (2002). Compensatory locomotor adjustments of rats with cervical or thoracic spinal cord hemisections. Journal of neurotrauma, 19(2), 239-256.

Woerly, S., Awosika, O., Zhao, P., Agbo, C., Gomez-Pinilla, F., de Vellis, J., et al. (2005). Expression of heat shock protein (HSP)25 and HSP-32 in the rat spinal cord reconstructed with Neurogel. Neurochemical research, 30(6-7), 721-735.

Woerly, S., Doan, V. D., Evans-Martin, F., Paramore, C. G., \& Peduzzi, J. D. (2001 a). Spinal cord reconstruction using NeuroGel implants and functional recovery after chronic injury. Journal of neuroscience research, 66(6), 1187-1197.

Woerly, S., Doan, V. D., Sosa, N., de Vellis, J., \& Espinosa, A. (2001 b). Reconstruction of the transected cat spinal cord following NeuroGel implantation: axonal tracing, immunohistochemical and ultrastructural studies. International journal of developmental neuroscience: the official journal of the International Society for Developmental Neuroscience, 19(1), 63-83.

Woerly, S., Doan, V. D., Sosa, N., de Vellis, J., \& Espinosa-Jeffrey, A. (2004). Prevention of gliotic scar formation by NeuroGel allows partial endogenous repair of transected cat spinal cord. Journal of neuroscience research, 75(2), 262-272.

Woerly, S., Petrov, P., Syková, E., Roitbak, T., Simonová, Z., \& Harvey, A. R. (1999). Neural tissue formation within porous hydrogels implanted in brain and spinal cord lesions: ultrastructural, immunohistochemical, and diffusion studies. Tissue engineering, 5(5), 467-488.

Woerly, S., Pinet, E., De Robertis, L., Bousmina, M., Laroche, G., Roitback, T., et al. (1998). Heterogeneous PHPMA hydrogels for tissue repair and axonal regeneration in the injured spinal cord. Journal of biomaterials science. Polymer edition, 9(7), 681-711.

Woerly, S., Pinet, E., de Robertis, L., Van Diep, D., \& Bousmina, M. (2001 c). Spinal cord repair with PHPMA hydrogel containing RGD peptides (NeuroGel). Biomaterials, 22(10), 1095-1111.

Woerly, S., Plant, G. W., \& Harvey, A. R. (1996). Cultured rat neuronal and glial cells entrapped within hydrogel polymer matrices: a potential tool for neural tissue replacement. Neuroscience letters, 205(3), 197-201.

Zavvarian, M. M., Hong, J., \& Fehlings, M. G. (2020). The Functional Role of Spinal Interneurons Following Traumatic Spinal Cord Injury. Frontiers in cellular neuroscience, 14, 127.

Zhang, Q., Shi, B., Ding, J., Yan, L., Thawani, J. P., Fu, C., et al. (2019). Polymer scaffolds facilitate spinal cord injury repair. Acta biomaterialia, 88, 57-77.

Zhang, Q., Yan, S., You, R., Kaplan, D. L., Liu, Y., Qu, J., et al. (2016). Multichannel silk protein/laminin grafts for spinal cord injury repair. Journal of biomedical materials research. Part A, 104(12), 3045-3057.

Zhang, Z., Nonaka, H., Nagayama, T., Hatori, T., Ihara, F., Zhang, L., et al. (2001). Circulatory disturbance of rat spinal cord induced by occluding ligation of the dorsal spinal vein. Acta neuropathologica, 102(4), 335-338.

Zhao, Y. Y., Yuan, Y., Chen, Y., Jiang, L., Liao, R. J., Wang, L., et al. (2015). Histamine promotes locomotion recovery after spinal cord hemisection via inhibiting astrocytic scar formation. CNS neuroscience \& therapeutics, 21(5), 454-462. 


\section{ЗАЛЕЖНІСТЬ ВІДНОВНОГО ВПЛИВУ МАКРОПОРИСТОГО ГІДРОГЕЛЮ НА ОСНОВІ N-(2-ГІДРОКСИПРОПІЛ) МЕТАКРИЛАМІДУ ВІД ТЯЖКОСТІ ЕКСПЕРИМЕНТАЛЬНОЇ ЛАЦЕРАЦИЙНОЇ ТРАВМИ СПИННОГО МОЗКУ}

\section{Абдалла Ібрагім ${ }^{1}$ Медведєв Володимир 2 , Драгунцова Наталія ${ }^{3}$, Войтенко Нана ${ }^{4}$, Цимбалюк Віталій}

${ }^{1}$ Аспірант кафедри нейрохірургії Національного медичного університету імені О.О. Богомольця, Україна

${ }^{2}$ Доктор медичних наук, доцент, професор кафедри нейрохірургії Національного медичного університету імені О.О. Богомольця, Україна

${ }^{3}$ Науковий співробітник лабораторії експериментальної нейрохірургії ДУ «Інститут нейрохірургії ім. акад. А.П. Ромоданова НАМН України», Україна

${ }^{4}$ Доктор біологічних наук, професор, завідуюча відділом сенсорної сигналізації Інституту фізіології імені О.О. Богомольця НАН України, Україна

${ }^{5}$ Доктор медичних наук, професор, академік НАН та НАМН України, завідувач кафедри нейрохірургії Національного медичного університету імені О.О. Богомольця, Україна

Анотація: відновлення втрачених функції травмованого спинного мозку - одна із найтяжчих біомедичних проблем сучасності. Метою даної роботи було з'ясування залежності відновного впливу макропористого гідрогелю на основі N-(2-гідроксипропіл)метакриламіду (hydrogel, HG) від ступеню лацераційної травми спинного мозку у молодому віці. Дослідження виконано на щурах-самцях (вік - 1 місяць, маса $-\sim 50$ г, інбредні похідні лінії Wistar), сформовано 4 експериментальні групи -1) бічний половинний перетин (sectio) спинного мозку на рівні сегментів $\sim \mathrm{T}_{12}-\mathrm{T}_{13}$ (Sect; $\left.\mathrm{n}=11\right) ; 2$ ) висічення (excisio) бічного половинного фрагменту спинного мозку довжиною $\sim 1$ мм на аналогічному рівні (Ехс; $\mathrm{n}=8)$; 3) бічний половинний перетин спинного мозку на аналогічному рівні і негайна імплантація у зону травми фрагменту гідрогелю (HGsect; $\mathrm{n}=11$ ); 4) висічення бічного половинного фрагменту спинного мозку на аналогічному рівні і негайна імплантація у зону дефекту фрагменту гідрогелю (HGexc; n=6). Оцінку рухової функції і спастичності задньої паретичної кінцівки здійснено, відповідно, за шкалою Basso-Beattie-Bresnahan (BBB) i Ashworth у власних технічних модифікаціях, одним експериментатором, умовно засліпленим стосовно індивідуальних

\section{ЗАВИСИМОСТЬ ВОССТАНОВИТЕЛЬНОГО ЭФФЕКТА МАКРОПОРИСТОГО ГИДРОГЕЛЯ НА ОСНОВЕ N-(2-ГИДРОКСИПРОПИЛ) МЕТАКРИЛАМИДА ОТ ТЯЖЕСТИ ЭКСПЕРИМЕНТАЛЬНОЙ ЛАЦЕРАЦИОННОЙ ТРАВМЫ СПИННОГО МОЗГА}

\author{
Абдалла Ибрагим ${ }^{1}$, Медведев Владимир 2 , \\ Драгунцова Наталия ${ }^{3}$, Войтенко Нана ${ }^{4}$, \\ Цимбалюк Віталій
}

${ }^{1}$ Аспирант кафедры нейрохирургии Нацинального медицинского университета имени А.А. Богомольц̧а, Украина

${ }^{2}$ Доктор медицинских наук, доцент, профессор кафедры нейрохирургии Нацинального медицинского университета имени А.А. Богомольца, Украина

${ }^{3}$ Научный сотрудник лаборатории экспериментальной нейрохирургии ГУ «Институт нейрохирургии им. акад. А.П. Ромоданова НАМН Украины», Украина

${ }^{4}$ Доктор биологических наук, профессор, заведующая отделом сенсорной сигнализации Института физиологии имени А.А. Богомольца НАН Украины, Украина

5 Доктор медицинских наук, профессор, академик НАН и НАМН Украины, заведующий кафедрой нейрохирургии Нацинального медицинского университета имени А.А. Богомольца, Украина

Аннотация: восстановление утраченых функций травмированного спинного мозга - одна из наиболее тяжелых биомедицинских проблем современности. Целью данной работы было изучение зависимости восстановительного эффекта имплантации аморфного макропористого гидрогеля на основе $\mathrm{N}$-(2-гидроксипропил)метакриламида (hydrogel, HG) от тяжести лацерационной травмы спинного мозга у молодых животных. Исследование выполнено на крысах-самцах (возраст - 1 мес, маса $-\sim 50$ г, инбредные производные линии Wistar), сформировано 4 экспериментальные группы - 1) боковое половинное пересечение (sectio) спинного мозга на уровне сегментов $\sim \mathrm{T}_{12}-\mathrm{T}_{13}(\mathrm{Sect} ; \mathrm{n}=11) ; 2$ ) иссечение (excisio) бокового поливинного фрагмента спинного мозга длиной $\sim 1$ мм на аналогичном уровне (Exc; $\mathrm{n}=8)$; 3) боковое половинное пересечение спинного мозга на аналогичном уровне и немедленная имплантация в зону травмы фрагмента гидрогеля (HGsect; $\mathrm{n}=11)$; 4) иссечение бокового половинного фрагмента спинного мозга на аналогичном уровне и немедленная имплантация в зону дефекта фрагмента гидрогеля (HGexc; n=6). Оценку двигательной функции и спастичности задней паретичной конечности осуществлено, соответственно, за шкалой Basso- 
ознак усіх прооперованих ним тварин і попередніх результатів тестування. Тривалість спостереження — 5 міс. Критерії невключення: рівень функції задньої іпсилатеральної кінцівки через 1 тиждень після травми $>9$ балів ВВВ, рівень функції задньої контрлатеральної кінцівки протягом тривалого періоду спостереження $\leq 14$ балів ВВВ. Представлення i аналіз результатів - згідно зі стандартизованою часовою сіткою з інтерполяційним відтворенням індивідуальних рівнів рухової функції і спастичності у вийняткових випадках. Асимптотичні відмінності реальних термінів спостереження порівнюваних груп і підгруп - протягом перших трьох тижнів, а також через 8 тиж і через 3 міс після травми. Було 3'ясовано, що через тиждень після травми рівень рухової функції у групі Ехс складав $0.9 \pm 0.5$ бала ВВВ, у групі HGexc - 3.6 \pm 1.2 бала, у групі Sect - 5.9 \pm 1.1

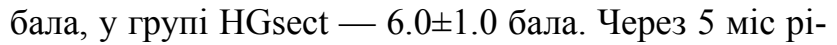
вень рухової функції у групі Sect становив $9.5 \pm 1.0$ бала BBB, у групі HGsect - 9.5 \pm 1.1 бала, у групі Ехс

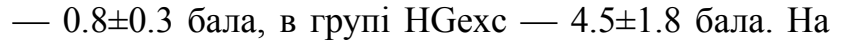
цьому ж терміні спостереження рівень спастичності у групах Sect i HGsect становив, відповідно, $0.8 \pm 0.2$ i $0.8 \pm 0.3$ бала Ashworth, у групі HGexc - $1.8 \pm 0.7$ бала, у групі Ехс - 3.6 \pm 0.3 бала. Протягом усього експерименту значущих відмінностей рівня рухової функції між групами Sect i HGsect не виявлено, а для груп Exc i HGexc - зафіксовано лише через 5 тиж після травми. Істотну різницю рівня спастичності для груп Sect i HGsect спостерігали через 1 тиждень після травми, для груп HGexc i Exc - протягом перших 2-х міс експерименту. Для груп Sect i Ехс достовірну різницю як рівня рухової функції, так і рівня спастичності виявляли на усіх термінах спостереження. Для груп HGsect i HGexc істотна різниця рівня рухової функції була характерною на усіх термінах, за виключенням кінця першого і 7-го тижня, тоді як відмінності рівня спастичності впродовж експерименту залишалися несуттєвими. Таким чином, апробований гідрогель у молодому віці проявляє істотний відновний вплив лише при травмі із об〉ємним дефектом речовини спинного мозку.

Ключові слова: травма спинного мозку, задня кінцівка, парез, м>язова спастичність, регенерація спинного мозку, гідрогелі.
Beattie-Bresnahan (BBB) и Ashworth, в наших технических модификациях, одним экспериментатором, условно заслепленным относительно индивидуальных признаков всех прооперованных им животных и предыдущих результатов тестирования. Длительность наблюдения - 5 мес. Критерии невключения: уровень функции задней ипсилатеральной конечности через 1 неделю после травмы $>9$ баллов ВВВ, уровень функции задней контрлатеральной конечности в течение длительного периода наблюдения $\leq 14$ баллов ВВВ. Представление и анализ результатов - согласно со стандартизированной временной сеткой с интерполяционным воспроизведением индивидуальных уровней двигательной функции и спастичности в исключительных случаях. Асимптотические различия реальных сроков тестирования сравниваемых групп и подгрупп - в течении первых трех недель, а также через 8 нед и через 3 мес после травмы. Было выявлено, что через неделю после травмы уровень двигательной функции в группе Ехс составлял $0.9 \pm 0.5$ балла ВBВ, в группе

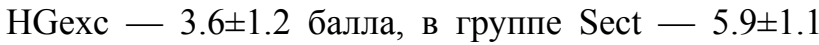

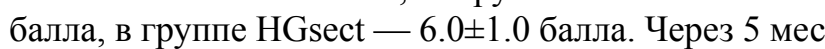
уровень двигательной функции в группе Sect составлял 9.5 \pm 1.0 балла BBB, в группе HGsect - 9.5 \pm 1.1 балла, в группе Еxс - $0.8 \pm 0.3$ балла, в группе HGexc - 4.5 \pm 1.8 балла. На этом же сроке наблюдения уровень спастичности в группах Sect и HGsect составил, соответственно, $0.8 \pm 0.2$ и $0.8 \pm 0.3$ балла Ashworth, в группе HGexc - $1.8 \pm 0.7$ балла, в группе Exc - 3.6 \pm 0.3 балла. В течение всего эксперимента значимых различий уровня двигательной функции между группами Sect и HGsect не выявлено, а для групп Ехс и HGexc - выявлено только через 5 нед после травмы. Достоверную разницу уровня спастичности для групп Sect и HGsect наблюдали через 1 неделю после травмы, для групп HGexc и Еxс в течение первых 2-х мес эксперимента. Для групп Sect и Ехс существенные отличия как уровня двигательной функци, так и уровня спастичности выявляли на всех сроках наблюдения. Для групп HGsect и HGexc достоверная разница уровня двигательной функции была характерна на всех сроках, за исключением конца первой и 7-й недели, тогда как отличия уровня спастичности в течение эксперимента оставались несущественными. Таким образом, апробированный гидрогель в молодом возрасте проявляет ощутимый положительный эффект только при более тяжелой форме травмы, со значительным пространственным дефектом спинного мозга.

Ключевые слова: травма спинного мозга, задняя конечность, парез, мышечная спастичность, регенерация спинного мозга, гидрогели. 